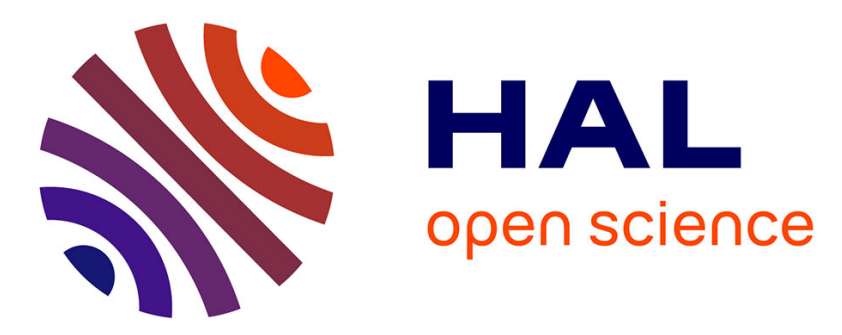

\title{
A Dissenting Voice in Alabama: Virginia Foster Durr's Correspondence (1951-68)
}

\author{
Anne Stefani
}

\section{To cite this version:}

Anne Stefani. A Dissenting Voice in Alabama: Virginia Foster Durr's Correspondence (1951-68).

Revue Française d'Etudes Américaines, 2009, 120, pp.65 - 78. 10.3917/rfea.120.0065 . hal-01482570

\section{HAL Id: hal-01482570 \\ https://hal-univ-tlse2.archives-ouvertes.fr/hal-01482570}

Submitted on 3 Mar 2017

HAL is a multi-disciplinary open access archive for the deposit and dissemination of scientific research documents, whether they are published or not. The documents may come from teaching and research institutions in France or abroad, or from public or private research centers.
L'archive ouverte pluridisciplinaire HAL, est destinée au dépôt et à la diffusion de documents scientifiques de niveau recherche, publiés ou non, émanant des établissements d'enseignement et de recherche français ou étrangers, des laboratoires publics ou privés. 


\section{A DISSENTING VOICE IN ALABAMA: VIRGINIA FOSTER DURR'S CORRESPONDENCE (1951-68)}

Anne Stefani

Belin | « Revue française d'études américaines »

2009/2 $\mathrm{n}^{\circ} 120 \mid$ pages 65 à 78

ISSN 0397-7870

ISBN 2701153544

Article disponible en ligne à l'adresse :

http://www.cairn.info/revue-francaise-d-etudes-americaines-2009-2-page-65.htm

Pour citer cet article :

Anne Stefani, «A Dissenting Voice in Alabama: Virginia Foster Durr's

Correspondence (1951-68) », Revue française d'études américaines 2009/2 (n 120), p. 65-78.

DOI $10.3917 /$ rfea.120.0065

Distribution électronique Cairn.info pour Belin.

(C) Belin. Tous droits réservés pour tous pays.

La reproduction ou représentation de cet article, notamment par photocopie, n'est autorisée que dans les limites des conditions générales d'utilisation du site ou, le cas échéant, des conditions générales de la licence souscrite par votre établissement. Toute autre reproduction ou représentation, en tout ou partie, sous quelque forme et de quelque manière que ce soit, est interdite sauf accord préalable et écrit de l'éditeur, en dehors des cas prévus par la législation en vigueur en France. Il est précisé que son stockage dans une base de données est également interdit. 


\title{
A Dissenting Voice in Alabama: Virginia Foster Durr's Correspondence (1951-68)
}

\author{
Anne STEFANI
}

\footnotetext{
mots-clés/key-words

États-Unis; Sud;

Virginia Durr; Mouvement des droits civiques; ségrégation;

déségrégation; réformistes blancs; dissidence; correspondance

United States; South; Virginia Durr; Civil Rights Movement; segregation; desegregation; white reformers; dissent; correspondence
}

Quel rôle la correspondance privée peut-elle jouer dans un contexte d'intolérance politique et sociale? L'analyse du cas de Virginia Durr, militante blanche intégrationniste dans le Sud des États-Unis, entre la Seconde Guerre mondiale et la fin des années 60 , permet de répondre à cette question. La publication, en 2003, d'une sélection de lettres écrites pendant la crise liée à la déségrégation, indique, en effet, l'importance particulière de ces écrits pour les réformistes blancs du Sud à cette époque. L'exemple de V. Durr, loin d'être isolé, est emblématique d'une tranche méconnue de la communauté blanche sudiste de l'époque, que les gardiens de la suprématie blanche tentèrent de réduire au silence. Dans un tel contexte, la correspondance privée remplit au moins trois fonctions. Elle peut tout d'abord permettre à la voix minoritaire, intégrationniste, de s'exprimer contre le consensus dominant, et de lutter contre l'ostracisme résultant de sa position dissidente. Elle permet également à l'individu de témoigner, pour le monde extérieur, sur la crise liée à la déségrégation dans la région - en particulier sur la répression exercée par les autorités régionales - et par là d'apporter sa contribution au mouvement des droits civiques. Enfin, la correspondance prend souvent la forme d'un appel à l'intervention extérieure contre les forces ségrégationnistes déterminées à empêcher toute forme de déségrégation.

Virginia Foster Durr, a white woman born in 1903 to an upper-class family in Alabama, devoted her life to the fight for social justice at a time when challenging racial and social norms in the segregated South 


\section{AnNe Stefani}

systematically entailed harassment and ostracism. During her twenty years spent in Washington, D.C., where her husband worked for the New Deal Administration, she grew familiar with prominent people of the time, from Eleanor Roosevelt to Congressman Lyndon Johnson and Supreme Court Justice Hugo Black, her brother-in-law. She was among the few Southern whites who actively supported the Civil Rights Movement from the Montgomery Bus Boycott in 1955-56 to the late sixties. ${ }^{1}$ The publication, in 2003, of the letters she wrote between 1951 and 1968-Freedom Writer: Virginia Foster Durr, Letters from the Civil Rights Years, edited by Patricia Sullivan - testifies to the important role played by Durr and a few other white Southern dissenters in the democratization of their society. The editor of the letters chose the year 1951 because this was the year when the Durrs reluctantly returned to their native South, after Cliff had left his federal job in Washington. ${ }^{2}$ This was three years before the U.S. Supreme Court declared school segregation unconstitutional, hence triggering both the desegregation process and massive resistance to it in the Southern states. ${ }^{3}$ In 1951, Durr was 48 years old and already had a long career of political activism behind her. For a reformer like her, returning South meant coming back to enemy territory.

Most of the letters collected in the book are directly connected to the Southern context. They were sent to friends and public figures both inside and outside the South. Durr's main correspondents were reformers who shared her political and racial views: Clark Foreman had been a member of the Roosevelt Administration and worked for various civil rights organizations; Corliss Lamont was a Marxist philosopher who supported civil rights causes and combated McCarthyism; her closest female friends, Anne Braden - a field organizer for the Southern Conference Educational Fundand Jessica Mitford, were both active in the struggle for civil rights in the fifties and sixties. Other correspondents included black and white civil rights activists such as Ella Baker, who worked with the Southern Christian Leadership Conference and the Student Nonviolent Coordinating Committee, or Charles Gomillion, a professor of sociology at Tuskegee Institute.

Such correspondence constitutes a rare document for historians of the South because it connects the story of an individual to the history of her region and nation. As a number of studies have demonstrated, many white Southerners disapproved of segregation and white supremacy, and they left behind hundreds of letters in which they voiced ideas and feelings that often were never heard in public (Egerton; Reed; Murray). ${ }^{4}$ Durr's experience is representative of the sense of alienation felt by the minority who had to struggle against the conformity imposed by their community. Through her letters, she portrayed herself as a dissenter in a hostile environment, but she also testified and contributed to the transformation of her society. Moreover, 
her letters constituted a useful medium to seek outside help when the local situation appeared desperate. Her correspondence is thus of particular interest because it contributes to a less stereotyped, more complex understanding of the South during the Civil Rights Movement.

\section{Dissenting}

Among the recurrent themes that emerge from seventeen years of correspondence, the most personal one is alienation. The letters also provide a clear view of the social, political and cultural norms that prevailed in the mid-twentieth-century segregated South. Since the whole segregation system was based on imposed social and political inequality, any questioning of the doctrine of white supremacy was a direct threat to the established order, ${ }^{5}$ and Durr kept complaining about this. For instance in 1955, during the Montgomery Bus Boycott, she wrote:

Underneath southern life there is a sort of swamp - such deep corruption, that it seeps through all the crevices and crannies of life. I find it interesting and I think to see the Negroes putting up such a wonderful fight is thrilling and to help them just a little is wonderful. But until it changes I could never like it. It is like living in a closed room all the time and simply struggling for air [...]. ${ }^{6}$

The sense of imprisonment described by Durr was quite similar to the feelings expressed by Anne Braden or by Lillian Smith in their respective autobiographical essays, The Wall Between and Killers of the Dream. ${ }^{7}$

The white supremacy doctrine rested on a very specific definition of Southern white womanhood, based on the ideal of the "Southern lady", a Southern version of the Victorian lady. ${ }^{8}$ Since youth, Durr had struggled against the pressure exerted by her family to make her fit this ideal. In her autobiography, she gave her own definition of the "Southern lady", presenting her sister as its perfect incarnation. Commenting on the attitude of her sister's husband, Hugo Black, she noted in 1975: "He wanted [their daughter] to be a sweet Southern lady and beautiful and charming. And Sister was all those things; she was beautiful and sweet and charming. Everybody adored her, and he above all. But after she married, I don't think Sister ever was able to have a free moment. That was the way girls were supposed to be anyway" (Barnard 47). ${ }^{9}$

In the segregated South at mid-twentieth century, white women, owing to their reproductive capacity, were still considered the guardians of the white race. The segregationists' fear of miscegenation-i.e. the mixing of black and white races through marriage or sexual intercourse-had turned white women into sacred pillars of white civilization. As such, they had to be protected from black men, but they were also expected to perpetuate the 


\section{AnNe Stefani}

system by teaching their children to conform strictly to segregationist rules. ${ }^{10}$ Thus, gender and race were inextricably linked in the culture of the segregated South. For a white woman of the upper class such as Durr, conforming to the rules was incompatible with the fight against segregation. It has been argued, however, that while white, middle or upper-class women of her time did not reject their status openly, a great deal of them gradually undermined the image of the Southern lady and quietly emancipated themselves by becoming involved in racial reform (Evans 95, 97, 107, 159). ${ }^{11}$ Several of Durr's letters to Anne Braden show that because it enabled women to share common feelings and ideas, private correspondence

played a part in this emancipation from standard Southern values. ${ }^{12}$ Writing in 1960 about Southern women after one of them had committed suicide, Durr thus observed:

The death wish is strong in many of them and rightly so because they have been so shut off from life. I don't just mean sex frustration, although that is part of it, but I mean just as the Negroes have been barred from life or they have tried to bar them, so have the women been barred from life so often, or the life they have been offered has been nothing but cotton candy. ${ }^{13}$

(202-203)

The sacredness of white womanhood, used as a justification for confining white women to closed households, went along with a mythmaking process started after the Civil War, which presented Southern society as an ideal civilization to be preserved forever (Goldfield 4-5, 20-21, 89-120). Durr fought daily against such a mythical South, which she considered a major obstacle to reform, but which she could not overtly denounce. In 1961, she wrote to her British friend Jessica Mitford:

I think the rest of the country is really taken in by the "myth" of the Old South and the beautiful women and white pillared mansions and faithful Negro slaves. The whole Civil War Centennial is taken so seriously and people seem to love Civil War books and so on. It is having a bad effect on the thinking of the country, this romantic dream of the South.

In such a context, any person who broke the consensus was labelled "radical," and was ostracized by the local community, if not harassed by the guardians of white supremacy - the Ku Klux Klan, White Citizens' Councils, and most politicians (Woods 143-144). Writing to friends and outsiders thus became a way to survive ostracism while at the same time defeating the enemies within by speaking out. Many letters describe the ostracizing process in detail, emphasizing its effectiveness. In 1959, she explained to Clark Foreman:

I am sure [Cliff] never had any idea of how absolutely he would be ostracized, not that people are so unpleasant, they simply leave us alone, the phone never rings, the people never come, and it gets worse all the time instead of better. I have tried 
joining things, Church groups, League of Women Voters, Human Relations Council, AAUW, Legislative Council, even the Society for the Prevention of Cruelty to Animals, but with the same result in all of the groups, no one is unpleasant but nothing ever comes of any of it, no one calls, no one comes, no one asks me to call, it is simply non-recognition.

Ostracism took many shapes and could also become official harassment. In the case of Virginia Durr and some of her friends working for desegregation in the fifties, it took the form of official hearings before the Senate Internal Security Subcommittee, led by Mississippi Senator James Eastland. Eastland and the segregationists took advantage of McCarthyism to target integrationists in the South, and organized several anti-subversive hearings in order to discredit them (Woods 43-47). The hearings held in March 1954 in New Orleans were organized to prove that Durr and her integrationist colleagues had been spies for the Communists in the forties. In the New Orleans case, they mainly discredited Eastland, as nobody really took the accusations seriously, but they were a painful experience for the victims. Durr did not write much about them, but she received many letters of support from all around the country. ${ }^{14}$ Since the hearings were public, it is probable that she was less desperate to voice her concerns through private letters. She later explained that this experience paradoxically liberated her: "In a way, I was grateful that my cover as a nice, proper Southern lady was blown by the hearing, because then I could begin to say what I really thought" (Barnard 271).

\section{Testifying}

If writing to people empathetic to her cause clearly played a liberating role in Durr's private life, it also provided her with a channel for civil rights activism. She contributed to the Southern Civil Rights Movement by establishing links between various individuals and groups, between whites and blacks, or between Northerners and Southerners. In Montgomery, she became acquainted with many members of the local black community and attended integrated prayer meetings organized by United Church Women (Barnard 245). She then worked closely with the leaders of the Montgomery Bus Boycott-Rosa Parks, whom she befriended, Martin Luther King Jr. and his wife, Ralph Abernathy, and E. D. Nixon, the local head of the NAACP (Barnard 277-282, 295) - and introduced them to her white correspondents (119-120). She also sent suggestions for actions to civil rights workers and organizations based in the North, with specific instructions as to which tactics should be employed, or the way money should be used to help. After the Boycott, she tried to convince the leaders of the Emergency Civil Liberties Committee in New York to sponsor voting registration campaigns in the 


\section{AnNe Stefani}

South (131-35, 141-42). She indeed offered an insider's view of local events that could not be fully understood from the outside.

Her correspondence provides insight into the events that were taking place in the South as the Civil Rights Movement unfolded, especially after the U.S. Supreme Court declared school segregation unconstitutional in the 1954 Brown v. Board of Education. As white supremacists organized resistance to desegregation and openly declared their hostility to reformers inside and outside the South, integrationists like Durr struggled to make themselves heard in the name of their minority in the South. Many letters were meant to denounce the violations of democracy and basic human rights that occurred every day in the region, at a time when a majority of local newspapers either advocated white supremacy, or, when they disapproved of discrimination and violence, were reluctant to condemn the South for it, preferring to show their region in a favourable light whenever they could. ${ }^{15}$ Since Northern newspapers covering the events usually relied on prominent Southern journalists for information and insight, they tended to minimize the most discouraging features of the context. After the extreme violence that followed the court-ordered desegregation of New Orleans's schools in 1960, Durr thus wrote to a friend:

I read the Sunday [New York Times] and the Nation and the New Republic and Izzy [Stone] and the Guardian and whatever else comes to hand, and I am continually amazed at the wishful thinking on the part of the rest of the country. They hail with delight when one Negro child among hundreds gets into a school, and do not realize nor seem to care that the screaming women in New Orleans are not just a small minority but represent the majority sentiment.

Correspondence of the civil rights years reveals that Durr considered herself a privileged but helpless witness, which only reinforced her need to write. As a resident of Montgomery, she and her husband supported the Bus Boycott. She not only related the events in detail in her letters, but she also analyzed them and put them in perspective. She noted that this boycott was different from other actions, because it had a national dimension, and because it owed its success to new determination and unity within the black community that had not previously existed $(108,111)$. The letters were a way for her to further the interests of the movement by publicizing it. In particular, she tried to bridge the gap between the new black leaders and white sympathizers who lived outside the South, putting them in contact so that the whites could, for instance, provide financial support (114-119). As the Movement spread, she continued playing the same role, reporting on the Freedom Rides, the Student Nonviolent Coordinating Committee's campaigns, or the 1965 Selma March from the vantage point of Montgomery (320-23).

As a Southerner, she was anxious to explain the South to nonSoutherners. For those who did not know the history of the region, many 
situations seemed absurd from the outside. Some letters have a clear didactic purpose, as demonstrated in the following 1960 extract: "I do not think you can understand the South unless you realize it is or was a defeated nation and defeat and despair and poverty and pride (false pride) have been its main characteristics. Do read [Wilbur J.] Cash's The Mind of the South before you even think of coming down here to write about it" (212). Such examples and a few others also reveal Durr's and all dissenters' love for their region in spite of its faults. This is especially striking in the letters where she contrasted Northerners with Southerners, as if writing were a way of reasserting Southern identity, albeit an unfavourable context:

I really have come to the conclusions that reconstructed Southerners are the most attractive people there are, they are not self-righteous like so many of our Yankee friends, they know from experience the ease of evil ways, and the difficulty breaking away from them, all of us have had to pay for our convictions so they are not held lightly, and I am of the opinion, which of course is very conceited that we emancipated Southerners are really prizes!

The phrase "reconstructed Southerners" emphasizes the existence of a positive South, as opposed to the racist, violent one. A major function of Durr's correspondence then seems to be the claim for another identity for the South, one of "good" Southerners worthy of respect and support. In 1954, after Senator Eastland had tried to discredit Franklin and Eleanor Roosevelt during the New Orleans hearings by associating them with radicals and Communists, Durr wrote to Mrs Roosevelt to thank her for her support. She ended her letter with the following words:

But, please, Mrs. Roosevelt, do not think that this man speaks for the South. Southerners are loyal to their friends, and we know that both you and your husband were friends of the South and wanted to help us [. . .] Come and visit us and see for yourself and you will find that the name of Roosevelt is still held in love and honor in the South.

Many passages in the letters highlight the extraordinary character of a tiny minority of Southerners. Such passages not only compensate for the author's pessimism, but they also do justice to those forgotten Southerners, as shown in the following extract from a letter written during the Montgomery Bus Boycott:

I wish some proper homage and honor could be paid to the people here who in spite of Hell and High Water are holding up the banner of liberty and fighting for their rights and in a very intelligent manner too. I have come to know them well and only regret my inability to help them as I would like to.

One way to help was to publicize the Movement and all its sympathizers. Several whites who had refused to comply with the white supremacy doctrine wrote books to defend their views; hence, the many 
references in Virginia Durr's correspondence to what she considered to be "good" books about the South. By drawing attention to their authors, she could contribute to the spirit of reform that existed in the South. She especially recommended Wilbur Cash's The Mind of the South, P.D. East's The Magnolia Jungle, Harper Lee's To Kill a Mocking Bird (226), and C. Vann Woodward's The Strange Career of Jim Crow (92), among others. These works were all very different in kind, but they offered an uncompromising view of the South and Southern culture. Cash and East were two journalists who described their region in a very personal, highly critical style; Lee denounced racial injustice in a novel considered now a classic for youth; Woodward was an authority in African American and Southern history.

\section{Calling for Outside Help}

For all those precious individuals who shared her commitment to equality and justice, Durr was well aware of the desperate situation in which Southern integrationists found themselves after World War II. She knew that desegregation could not occur in the South without federal intervention, especially in 1956 after a crushing majority of Southern politicians declared that they would resist the Brown decision declaring school segregation unconstitutional. ${ }^{16}$ As the States' Rights doctrine was revived, segregationist leaders opposed all forms of federal intervention against segregation, which they considered a state matter. If the Warren Supreme Court was determined to support the fight for equality, the other branches of the Federal Government were more reluctant to antagonize Southern white politicians and voters. Indeed, up to the late fifties, Southern Congressmen and Senators remained key members of a powerful conservative coalition in the Federal Congress that prevented the passage of civil rights legislation (Lawson xvi-xvii, 140-202).

Familiar with Washington politics, Virginia Durr used her political connections to call for federal action to support the Civil Rights Movement in the fifties and sixties. She supported a bill banning discrimination against members of the armed services in all public places (181). From 1959 on, she wrote several times to Lyndon Johnson, Majority Leader of the U.S. Senate, to convince him of the necessity for Congress to act against segregation: "I go on the premise that you and I agree that the Southern system of segregation has to end. I do not think it can all be left to the U.S. Supreme Court with the accompanying demonstrations and resistance and defiance of the law and that Congress must act" (229-30). She went on trying to influence his action in favour of civil rights after he became Vice-President $(253,257,261)$. 
During the Kennedy Administration, she corresponded with Burke Marshall, Assistant Attorney General for civil rights, both to provide him with information about the local situation and suggest action in favour of civil rights (244-253). Like the members of SNCC, who kept asking the Federal Government for protection in the face of white violence (especially during the Freedom Rides and voting registration campaigns in the Deep South), she stressed the ambiguity of federal authorities in their relationship to the Civil Rights Movement. In her letters to Marshall, she pointed out the discrepancy between the apparent good will of the Kennedy Administration and appointments in the South of federal judges and other officials who openly supported segregationists against integrationists. Durr was not an active participant in the demonstrations and civil rights campaigns of the sixties. She considered the Movement belonged to the blacks running it, and that whites should not be on the frontline (114), but she knew that she could play her part in a less spectacular but more effective way, by reaching the most influential individuals through her letters. ${ }^{17}$ She thus wrote to Marshall in 1961:

I believe you to be an honest man, I hear you are, and I think Robert Kennedy wants to do a good job, but how can we believe in any speeches when the MEN who are appointed are the worst enemies of integration? I am afraid the patience of the Negroes is coming to an end and it will not be long before they meet violence with violence, they will get killed I know, and it is a suicidal thing to do, but as one of them told me "at least we will take some white men with us." 18

Marshall had actually asked her to send him information about local events, as the Justice Department, under Robert Kennedy's authority, seemed determined to enforce desegregation in the South. Yet, the Kennedy Administration was faced with open defiance from Southern governors in Mississippi and Alabama, who used local police forces to repress civil rights protesters, labelled "agitators." The segregationists opposed any intervention by the FBI on the grounds that the states, not the Federal Government, were in charge of local law and order (Carson 84-89; Zinn 192-199; Payne 107110, 116-124). Durr continued to correspond with members of the Kennedy Administration, notably Marshall and Johnson-her letters to Johnson actually sounding more like lobbying than collaboration (257) - but they seemed unable to cope with the issue of local white violence.

Even if her letters to federal officials show her involvement in political and social reform, as well as her faith in the American democratic system, the bulk of the correspondence is pessimistic. In her letters to people in the North, she often presented the desegregation crisis as a crucial, national issue, jeopardizing the future of American democracy. Durr reserved such personal thoughts to her friends, probably because they occurred in moments when she felt desperate. One letter dated November 5, 1963 is 
especially striking. As the nonviolent Civil Rights Movement was reaching its peak, a few months after the March on Washington, Durr did not see any progress being made, and despaired of the situation. She actually noted a movement of re-segregation in Atlanta, and feared that blacks might become violent in response to local repression (286-289).

In her call for outside help, she seemed to have lost faith in the power of politics to defeat the segregationist South, as in the following extract, written in 1959:

Until people in the rest of the country realize that this southern situation is part of the overall rottenness that infects the country and stop thinking of us as different and do something toward making the Federal government and northern industry stand up and take definite action, all the pious good wishes really don't make any sense.

Such statements show that writing was a way to articulate a social and political discourse that could hardly be tolerated in the Southern context, but one that needed to be heard and discussed by as many Americans as possible, as it not only concerned the South but the nation as a whole. This was especially crucial during the desegregation crisis, but letters written before and after the crisis confirm their author's interest in political theories and views which were highly unpopular in the South and which she could only share with close friends such as Clark Foreman or Corliss Lamont. She was never a Communist herself, but always resisted anti-Communism and favoured debate whenever she could. From the early thirties to the eighties, she kept reflecting on Communism and Socialism with Lamont, finding in correspondence the best means to convey her views. ${ }^{19}$

Durr did not stop fighting, nor writing, even after 1968, which marked the end of the Civil Rights Movement after segregation was officially abolished by the federal Civil Rights Act of 1964 and Voting Rights Act of 1965. She remained in Alabama, and devoted herself to the economic and political issues that had always preoccupied her. She worked with antipoverty organizations as well as for the Democratic Party. In 1985, she published her autobiography, based on a series of oral history interviews she had given in the mid-seventies. Patricia Sullivan, who edited her correspondence from the civil rights years, notes that she wanted the autobiography to end in 1945, finding the following part of her life too painful to write about. The autobiography was a success, and Sullivan writes: "After the long years of isolation and efforts to avoid publicity for fear of repercussions, going public with such acclaim was a vindication of sorts" (421). The publication of her letters from the civil rights era is indeed a welcome second vindication for her, but it is also an invitation to probe further into the lives and experiences of her correspondents, some of whom still remain too little known to the public. 
ANNE STEFanI is maittre de conférences in American civilisation at the Universite de Toulouse II-Le Mirail. Her research focuses on the South of the United States in the twentieth century, and more particularly on politics and society, Southern identity, racial segregation and integration, the Civil Rights Movement, women and Southern society. She is currently working on integrationist white women from the 1920s to the 1970s. One of her latest publications is "White Women and the Fight for Equality in the Southern United States (1920-1964): A Specific Brand of Activism”, @mnis, Revue de Civilisation Contemporaine de l'Université de Bretagne Occidentale EUROPES / AMÉRIQUES, http://www. univ-brest.fr/amnis/, novembre 2008.v-brest.fr/amnis/, novembre 2008.

\section{OUVRAGES CITÉS}

Arsenault, Raymond. Freedom Riders: 1961 and the Struggle for Racial Justice. New York: Oxford UP, 2006.

BARNARD, Hollinger F., ed. Outside the Magic Circle: The Autobiography of Virginia Foster Durr. Tuscaloosa: U of Alabama P, 1985.

Braden, Anne. The Wall Between. New York: Monthly Review P, 1958.

Carson, Clayborne. In Struggle: SNCC and the Black Awakening of the 1960s. Cambridge: Harvard UP, 1981.

CASH, Wilbur. The Mind of the South. 1941. New York: Random, 1991.

"Declaration of Constitutional Principles," Congressional Record, $84^{\text {th }}$ Congress, $2^{\text {nd }}$ session.

Washington DC: Government Printing Office, 1956: 4515-4516.

EgerTon, John. Speak Now Against the Day: The Generation Before the Civil Rights Movement in the South. New York: Knopf, 1994.

Evans, Sara M., ed. Journeys That Opened Up the World: Women, Student Christian Movements, and Social Justice, 1955-1975. New Brunswick: Rutgers UP, 2003.

Gladney, Margaret Rose, ed. How Am I to Be Heard? Letters of Lillian Smith. Chapel Hill: U of North Carolina P, 1993.

GoLDFIELD, David. Still Fighting the Civil War: The American South and Southern History. Baton Rouge: Louisiana State UP, 2002.

HaLl, Jacquelyn Dowd. Revolt Against Chivalry: Jessie Daniel Ames and the Women's Campaign Against Lynching, rev. ed. New York: Columbia UP, 1993.

LaWSON, Steven F. Black Ballots: Voting Rights in the South, 1944-1969. Lanham: Lexington Books, 1999 (1976).

MurraY, Gail, ed. Throwing Off the Cloak of Privilege: Southern White Women Activists in the Era of Civil Rights. Gainesville: UP of Florida, 2004.

OLson, Lynne. Freedom's Daughters: The Unsung Heroines of the Civil Rights Movement from 1830 to 1970. New York: Touchstone, 2001. 


\section{AnNe Stefani}

Payne, Charles M. I've Got the Light of Freedom: The Organizing

Tradition and the Mississippi Freedom Struggle. Berkeley: U of California P, 1995.

REED, Linda. Simple Decency and Common Sense: The Southern Conference Movement, 1938-1963. Bloomington and Indianapolis: Indiana UP, 1991.

ScotT, Anne Firor. The Southern Lady: From Pedestal to Politics, 1830-1930. Charlottesville: UP of Virginia, 1995 (1970).

Sмith, Lillian. Killers of the Dream. New York: Norton, 1961.

Stanton, Mary. Journey toward Justice: Juliette Hampton Morgan and the Montgomery Bus Boycott. Athens: U of Georgia P, 2006.

Sullivan, Patricia, ed. Freedom Writer: Virginia Foster Durr, Letters from the Civil Rights Years. New York: Routledge, 2003.

Woons, Jeff. Black Struggle, Red Scare: Segregation and Anti-
Communism in the South, 19481968. Baton Rouge: Louisiana State UP, 2004.

ZINN, Howard. SNCC: The New Abolitionists. 1964. Cambridge: South End, 2002.

\section{Manuscript Collections:}

Carl and Anne Braden Papers.

State Historical Society of Wisconsin, Madison.

Virginia Foster Durr Papers. Schlesinger Library, Radcliffe Institute for Advanced Sudies, Harvard University.

Thrasher, Sue and Jacquelyn Hall, Interview of Virginia Foster Durr, March 13, 14, 15, 1975. Interview G-0023-1. Southern Oral History Program Collection (\#4007). University of North Carolina at Chapel Hill. 
1. The phrase "the Civil Rights Movement" commonly refers to the nonviolent movement against segregation beginning in December 1955 with the Montgomery Bus Boycott, and lasting throughout the sixties (branching out to the Black Power Movement after 1966). Some participants tend to prefer the phrase "Freedom Movement" when recalling their experience. In recent decades, however, historians have sometimes used "the Civil Rights movement" in a broader sense to designate the various forms of struggle against discrimination that took shape earlier in the twentieth century but were not clearly identified as a movement.

2. Before returning to the South, the Durrs had lived in the Washington, D.C. area. During those years, Cliff worked for the New Deal Administration - first for the Reconstruction Finance Corporation, then for the Federal Communications Commission-while Virginia fought against racial discrimination. She especially used her acquaintances with Eleanor Roosevelt and a few Congressmen and Senators to campaign for the passage of a federal antipoll tax law - the poll tax being then one of the major obstacles to black franchise. She later worked for Henry Wallace and the Progressive Party in the 1948 presidential campaign (Barnard 114-170, 195-201). Cliff then left his federal job in protest against the loyalty programs imposed by President Truman on federal employees at the beginning of the Cold War. His (and his wife's) non-conformist political views left him no other choice but to open a private law practice in his native town.

3. Brown v. Board of Education, 347 U.S. 483 (1954). In 1955 the Supreme Court handed down a second decision ordering the states to desegregate their schools "with all deliberate speed" [349 US 294 (1955)]. In 1956, Southern Congressmen and Senators in the Federal Congress reacted by signing the Southern Manifesto, in which they argued against the legitimacy and constitutionality of the Brown decisions, and called on the states to resist their implementation. See "Declaration of Constitutional Principles"-the official name for the manifesto-in the bibliography.

4. Lillian Smith's correspondence is a particularly good example (Gladney). (Cash 90-91).

5. This Southern version of intolerance was what Wilbur Cash called the "savage ideal"

6. When not specified, all page numbers refer to Freedom Writer: Virginia Foster Durr, Letters from the Civil Rights Years, edited by Patricia Sullivan.

7. See Sullivan 29,35-36ff. This is also a pervasive theme of Braden's unpublished correspondence.

8. The classic study of the "Southern lady" is Scott's The Southern Lady: From Pedestal to Politics, 1830-1930. See also Hall's Revolt Against Chivalry, Smith's Killers of the Dream, and the introduction to Throwing Off the Cloak of Privilege (Murray).

9 . The autobiography was actually based on several interviews which are part of oral history programs. The quoted passage was taken from Interview G-0023-1, Southern Oral History Program Collection (93).

10. For another personal account of this fact, see, for instance, Lillian Smith's Killers of the Dream.

11. See the examples of Anne Braden, Dorothy Tilly, Katharine Du Pre Lumpkin, Lucy Randolph Mason, Sarah Patton Boyle, among others.

12. Lynne Olson sums up Durr's own emancipation in the following terms: "Durr, who from childhood had made a close study of well brought-up Southern white women, finally decided that there were only three options available to her: become an actress and play the Southern belle; go crazy like Blanche DuBois; or become a rebel, step outside the magic circle, and challenge the Southern way of life. Durr chose the third option (Olson 99)."

13. Braden developed similar views in her own letters. See Anne Braden to V. Durr, April 19, 1959, folder 7, box 56, Braden Papers, and A. Braden to V. Durr, April 20, 1959, folder 103, carton 2, Durr Papers. They reacted to the death of Juliette Morgan, a librarian in Montgomery who had committed suicide. She had been harassed by local segregationists for 


\section{AnNe Stefani}

publicly supporting the Montgomery Boycott and the integrationist movement in 1956 (see Stanton). It should be noted that the quotation concerns white women, even if this is not clearly specified. In the Southern context, white women's experience actually differed from black women's, due to the long history of slavery and segregation. Such a difference indeed made it difficult for black and white women to work together all through the Civil Rights Movement. As writer Marita Golden observes: "We have been defined as symbolic and actual opposites. The white woman weak/the black woman strong, the white woman undersexed/the black woman oversexed, the white woman the symbol of sexual desire/the black woman neutered. And this mumbo jumbo of imprisoning, corrupting imagery still rages in our heads and in our hearts, and makes it all the more difficult to throw a life or love line to one another" (Olson 16).

14. Folder 33, carton 1, Durr Papers.

15. Many examples could be used to illustrate this point. Among them, the Richmond News-Leader was a typical example of the segregationist side, while the Atlanta Constitution represented the liberal press.

16. See "Declaration of Constitutional Principles."

17. She also helped by accommodating protesters in her house whenever she could. She was especially supportive of SNCC's leaders James Forman and John Lewis, between 1961 and 1964 (Barnard 322-325).

18. Here she refers to the violence used against the Freedom Riders in 1961. Black and white integrationists had traveled together on interstate buses from North to South, to expose the fact that Southern states did not respect Supreme Court decisions that had declared interstate travel segregation unconstitutional (Henderson v. United States, 339 US 816, 1950, and Boynton v. Virginia, 364 US 454, 1960). The Freedom Riders' arrival in Anniston and Birmingham, Alabama, caused riots as the local segregationists assaulted them. There are many accounts about the ensuing events. See for instance Carson's chapter 3, or Arsenault's recent study. As for the federal judge mentioned by Durr, his name was Ben Hardeman.

19. See the correspondence with Corliss Lamont, folders 178-185, carton 3, Durr Papers. 